\title{
EDUCATIONAL SYSTEMS OF EASTERN EUROPEAN COUNTRIES AS A SUBJECT OF INTERNATIONAL COMPARATIVE RESEARCH
}
SISTEMAS EDUCACIONAIS DOS PAÍSES DA EUROPA ORIENTAL COMO OBJETO DE PESQUISA COMPARATIVA INTERNACIONAL

\section{SISTEMAS EDUCATIVOS DE DOS PAÍSES DE EUROPA ORIENTAL COMO OBJETO DE PESQUISA COMPARATIVA INTERNACIONAL}

\author{
Tetiana Dudka ${ }^{1}$ \\ Mykola Chumak ${ }^{2}$ \\ Nina Lytvynenko ${ }^{3}$ \\ Valentuna Benera ${ }^{4}$ \\ Tamara Serhiienko ${ }^{5}$
}

\begin{abstract}
The article analyzes the level of development of educational systems in Eastern European countries by using empirical data from international comparative studies. The tools of comparative analysis are used to group the studied publications, which directly or indirectly consider an educational system at the level of different countries and regions of the world. The newest western approaches to the issue of educational systems are represented. The unsurpassed value of multi-object international comparative research in the study of educational systems of the world enabling the analysis of the phenomenon at the interdisciplinary level is emphasized. The author's definition of "international comparative research" is formulated based on modern scientific studies, which is interpreted as a special type of research, which purpose is to conduct multilevel analysis to compare macro-objects, based on subjective empirical data. Emphasis is done on the lack of a unified terminological apparatus of the studied issue in modern science, which indicates the availability of the following definitive plurality: "comparative studies", "international issues", "cross-cultural studies", and "international comparative studies". The analysis of the level of development of educational systems of Eastern European countries is based on a comparison of official statistical materials of the World Bank. The processed statistical materials are correlated with the results of descriptive statistics during the testing of statistical hypotheses. Subject analysis of educational systems in Eastern Europe is based on a comparison of empirical data on three criteria - international educational projects, the highest educational results ("S.A.B.E.R"), and the amount of external funding for the educational branch.
\end{abstract}

\footnotetext{
${ }^{1}$ National Pedagogical Dragomanov University, Kyiv, Ukraine.

${ }^{2}$ National Pedagogical Dragomanov University, Kyiv, Ukraine.

${ }^{3}$ Bogomolets National Medical University, Kyiv, Ukraine.

${ }^{4}$ Taras Shevchenko Regional Humanitarian-Pedagogical Academy of Kremenets, Kremenets, Ukraine.

${ }^{5}$ Bogomolets National Medical University, Kyiv, Ukraine.
} 
Key words: Educational system, Eastern European countries, international comparative studies

Resumo: $\mathrm{O}$ artigo analisa o nível de desenvolvimento de sistemas educacionais nos países da Europa Oriental usando dados empíricos de estudos comparativos internacionais. As ferramentas de análise comparativa são usadas para agrupar as publicações estudadas, que consideram direta ou indiretamente um sistema educacional no nível de diferentes países e regiões do mundo. As mais recentes abordagens ocidentais da questão dos sistemas educacionais estão representadas. É enfatizado o valor insuperável da pesquisa comparativa internacional de múltiplos objetos no estudo dos sistemas educacionais do mundo, permitindo a análise do fenômeno no nível interdisciplinar. A definição do autor de "pesquisa comparativa internacional" é formulada com base em estudos científicos modernos, interpretados como um tipo especial de pesquisa, cujo objetivo é realizar análises multiníveis para comparar objetos macro, com base em dados empíricos subjetivos. Ênfase é feita na falta de um aparato terminológico unificado da questão estudada na ciência moderna, que indica a disponibilidade da seguinte pluralidade definitiva: "estudos comparativos", "questões internacionais", "estudos interculturais" e "comparativos internacionais estudos". A análise do nível de desenvolvimento dos sistemas educacionais dos países da Europa Oriental baseia-se na comparação de materiais estatísticos oficiais do Banco Mundial. Os materiais estatísticos processados são correlacionados com os resultados da estatística descritiva durante o teste de hipóteses estatísticas. A análise de sujeitos dos sistemas educacionais na Europa Oriental baseia-se na comparação de dados empíricos em três critérios - projetos educacionais internacionais, os mais altos resultados educacionais ("S.A.B.E.R") e a quantidade de financiamento externo para o ramo educacional.

Palavras-chave: Sistema educacional, países da Europa Oriental, estudos comparativos internacionais

Resumen: El artículo analiza el nivel de desarrollo de los sistemas educativos en los países de Europa del Este mediante el uso de datos empíricos de estudios comparativos internacionales. Las herramientas de análisis comparativo se utilizan para agrupar las publicaciones estudiadas, que consideran directa o indirectamente un sistema educativo a nivel de diferentes países y regiones del mundo. Los nuevos enfoques occidentales sobre el tema de los sistemas educativos están representados. Se enfatiza el valor insuperable de la investigación comparativa internacional de múltiples objetos en el estudio de los sistemas educativos del mundo que permite el análisis del fenómeno a nivel interdisciplinario. La definición del autor de "investigación comparativa internacional" está formulada en base a estudios científicos modernos, que se interpreta como un tipo especial de investigación, cuyo propósito es realizar análisis multinivel para comparar macroobjetos, basados en datos empíricos subjetivos. Se hace hincapié en la falta de un aparato terminológico unificado de la cuestión estudiada en la ciencia moderna, lo que indica la disponibilidad de la siguiente pluralidad definitiva: "estudios comparativos", "cuestiones internacionales", "estudios interculturales" y "estudios comparativos internacionales estudios". El análisis del nivel de desarrollo de los sistemas educativos de los países de Europa del Este se basa en una comparación de materiales estadísticos oficiales del Banco Mundial. Los materiales estadísticos procesados están correlacionados con los resultados de estadísticas descriptivas durante la prueba de hipótesis estadísticas. El análisis temático de los sistemas educativos en Europa del Este se basa en una comparación de datos empíricos en tres criterios: proyectos educativos internacionales, los resultados educativos más altos ("S.A.B.E.R") y la cantidad de financiamiento externo para la rama educativa.

Palabras clave: Sistema educativo, países de Europa del Este, estudios comparativos internacionales 


\section{INTRODUCTION}

A competitive educational system for every country in the world is a prerequisite for sustainable development and social progress. The effectiveness of the educational system directly depends on the redistribution and efficiency of the use of limited resources involved in this process. All issues related to the argument of the mechanism of efficient redistribution of resources within a particular industry remain the most controversial for many countries around the world. However, not every countryparticipant in the Global market considers the educational system a priority source of income, which can be multiplied due to highly skilled human capital. Underestimation of this situation by some countries leads to the fact that strategic guidelines for their sustainable development become unattainable. Therefore, making the right and strategically sound decisions should be based on the most accurate international indicators of branch development. In particular, the compliance of such indicators with the accuracy criteria is ensured by high requirements for the quality of international comparative studies.

Empirical data from international comparative studies are taken into account when modeling social processes and evaluating the effectiveness of state and international socially-oriented programs. Therefore, the objective need to involve the sample results of international comparative studies to optimize the work of educational systems in different countries and regions of the world is beyond doubt. The data of international comparative studies are especially valuable for the countries of Eastern Europe, which differ in the level of social and economic development (Shmygol et al., 2020; Yankovyi et al., 2020). The availability of such a "disproportion" within this European region is to some extent a consequence of the foreign policy of isolationism, a component of ideological programs of the previous century.

Today, all the countries of Eastern Europe have favorable conditions for the institutionalization of comparative research in the framework of harmonization of international relations. The publication of data from international comparative studies stimulates the development of optimal strategies for the development of educational systems in different countries, actualizes the expansion of the geography of international cooperation, and produces an exchange of experiences. Unfortunately, not every Eastern European country is focused on using the potential of international comparative research to further reform its educational systems. The imbalance of levels of educational background between the countries of the European region as a whole reduces the potential opportunities for professional selfrealization of the average graduate in the international labor market.

\section{LITERATURE REVIEW}

The relevance of considering the issue of development of educational systems is argued by the topics of scientific works, dedicated to the consideration of the destructive impact of the global pandemic on the world's education systems (Martinez, 2020); realities and prospects for further development of education systems worldwide (Hansen, Young, 2019), the impact of strategic educational management on the development of educational systems as a holistic complex (Waslander, Hooge, Theisens, Cissy, 2018); social and professional designing of the further development of the educational system taking into account the demands of modern vocational education (Szerletics, Rodak, 2017; Dudka, Gurzhii, Kartashova, Sorochan, Spitsyna, 2020); level of development of the educational system in different countries (Mineo, 2020; Ralhan, 2020; Rodberg, 2019; Sonnemann, 2019; Rehmat, 2020; Osmond-Johnson, Campbell , 2018; Ustun, Eryilmaz, 2018); efficiency of the impact of Eastern European membership in the EU on educational systems in general (Bergbauer, 2019); modernization aspirations of modern educational policies in Central and Eastern Europe (Gawlicz, Starnawski, 2018); the level of development of higher education in Western and Eastern Europe on a comparative basis 
(Mysíková, Večerník, 2019; Kvitka et al., 2019); interdependence of productivity of development of educational system and the quality of teaching of English (Griffith, 2019; Bodnar, Mirkovich, Koval, 2019); the level of coherence of higher education indicators in Central and Eastern Europe (Panić, Lozanov-Crvenković, 2019; Guglielmi, 2019).

Today, the analysis of the results of international comparative studies on the development of educational systems at the level of different regions of the world is quite timely and relevant. Intraindustry problems and tasks remain unresolved, which is reflected in the inefficient redistribution of available resources, lack of highly qualified staff, the inconsistency of strategic guidelines for sustainable development of the world regions (Kostetska et al., 2020), and the incompliance of the quality of education of the average graduate with modern world requirements. The latter fact can be explained in particular by the fact that social, economic, and international relations are quite volatile, and therefore the emergence of new risks activates researchers to develop effective approaches to address existing imbalances (Nazarova et al., 2019). The above-mentioned facts actualize the consideration of the stated problem by analyzing the theoretical and methodological basis and the available empirical data that reflect the real situation in terms of quantitative indicators and represented criteria.

The purpose of the article is to conduct a systematic analysis of the problem by analyzing the available conceptual framework at the theoretical and methodological level; to outline the level of development of educational systems of Eastern European countries based on empirical data of international comparative studies of the World Bank in recent decades.

\section{RESEARCH METHODS}

To achieve the goal of the research, certain scientific methods should be involved. They are as follows: theoretical (analysis of thematic works of researchers concerning the problem of education systems at the level of different countries and regions of the world; systematization of data in the course of grouping relevant research results; modeling education system as a holistic social and cultural phenomenon); empirical (comparative analysis in the process of comparing empirical data on the criteria of the number of international educational projects, the highest educational results and the amount of external funding); statistical (descriptive statistics and testing of statistical hypotheses in the process of author's argumentation of the research results).

\section{RESULTS}

In recent decades, the number of international comparative studies has been gradually increasing. The temporal, thematic, and subject scale of such studies are variable but their absolute number remains quite low. The latter trend is explained by the high cost and resource costs required to solve the mandatory methodological tasks.

The scientific value of international comparative research of educational systems lies in the importance of social information and applied functions. In particular, the evaluation of the effectiveness of national and international social programs aimed at studying the available educational experience of different countries is focused on avoiding current problems. The impact of international comparative research on social progress, in general, is difficult to overestimate. Quantitative indicators of such research are, in a sense, a path to social self-reflection; the way of reproducing social life, phenomena, and processes through in terms of specific parameters and data. Discrepancies and errors in the content 
of international comparative studies lead to a shift in numerical indicators, the formulation of erroneous conclusions, and, as a consequence, the deformation of the author's interpretations.

The methodology of international comparative research is based on the idea of combining the methods and procedures used in a particular country to compare the results and draw reliable conclusions. Today, those scientists who focus on the methodology of international comparative research are working on the development and justification of a comparative and target-oriented approach. The latter is based on a combination of criteria and procedures used at all stages of the study: from the formulation of goals and objectives to the final stage - subject analysis and reasoned interpretation of data. Thus, the comparative and target-oriented approach aims to minimize the overall error of the study in each country - the object of study and maximize the equivalence of data for each studied unit.

In general, international comparative research is a special type of research. It differs from a mono-object study as it is based on the analysis of data from one country. This feature can be explained by the fact that in modern science, there is no unified conceptual and categorical apparatus of this research area. In modern educational discourse, the terms "comparative research", "international issues", "cross-cultural research", "international comparative research" are widely used. The latter was used in our study because the main source of empirical data for the research was the official data of the World Bank. Its official website uses this term (World Bank, 2020). We used the definition of "international" to emphasize the subject-matter area of the research - the comparison of empirical data from around the world.

In general, we can assume that such a terminological plurality once again confirms the relevance of the studied issue. To argue the latter author's position, it should be emphasized that international comparative studies intensify the following:

- the development of several scientific directions;

- the improvement of methodological approaches and methods;

- the reflection of empirical data and formulation of substantiated conclusions;

- expanding international cooperation and encouraging the exchange of progressive experience;

- the involvement of a domestic scientific community in the international scientific incorporation.

In addition to the conceptual and categorical apparatus, the criteria of comparison, conceptual and metric equivalence, and invariant measurability remain debatable in international comparative studies. Another problem with the successful implementation of international comparative research is multilingualism. The priority given to the mechanical approach to the translation satisfies only the applied aspect, while the theoretical and methodological analysis remains out of the researcher's attention.

In general, international comparative research has become an informal laboratory. Its activities are aimed at developing new methods, practices, and standards that guide the researcher to improve methods of collecting information and their further analysis. In this regard, the main task of the researcher is to comprehensively develop a holistic model of comparative research, because a single subject of study unites all the countries studied. The rationality of solving the problem is achieved by the maximum adaptation of the author's theory to the results of the international comparative study. This approach allows for minimizing discrepancies and errors at the level of empirical data. Taking into account the above argumentation, the author gave the definition of "international comparative 
research", which means a special type of research, which purpose is to conduct a multilevel analysis to compare macro-objects, based on subjective empirical data.

Today, international comparative research is one of the most complex scientific phenomena in theoretical, methodological, and practical aspects. It is also one of the most promising research in the branch of education. The following studies actualize:

- the expanding of the education branch potential, as it serves as a strong argument for further branch reform;

- the formation of a holistic platform for the development and testing of working hypotheses in different social and cultural conditions of the world;

- the solution of urgent tasks of applied and theoretical content.

- international comparative research intensifies the reflection of the existing social and cultural reality, expands the understanding of national identity, and promotes the analysis in terms of empirical units of measurement.

As far as the research topic concerns the consideration of the issue of educational systems of Eastern European countries, therefore it requires the involvement of relevant empirical data in the research. In particular, our study used official data from the World Bank, which performs an appropriate regulatory function in maintaining the viability of international educational projects. The latter are represented at the level of specific numerical indicators that reflect the level of development of the studied phenomenon against in comparison with other regions of the world (in particular, "Africa, East Asia and the Pacific, Europe and Central Asia, Latin America and the Caribbean, Middle East and North Africa, and South Africa") (World Bank, 2020). These regions are divided into countries that are parts of them. Numerical sections are presented using complex thematic maps, united under the name "Smarter Education Systems to Achieve Learning for All" and developed taking into account specific criteria (World Bank, 2020).

The first thematic map is called "Projects" (World Bank, 2020). It presents the numerical indicators of relevant international educational projects in eight sub-sectors - "... preschool education, primary education, secondary education, vocational training, higher education, non-formal education, and adult education" (World Bank, 2020). Conditional gradation of international educational projects by specific sub-sectors reflects their main purpose, in particular:

- preschool education is focused on the exchange of progressive experience to improve the current system;

- primary and secondary education is aimed at providing quality education by forming the most significant key competencies of a student ();

- professional training is aimed at promoting academic mobility and improving the quality of teaching subjects, which content must meet the modern requirements of the labor market;

- higher education is focused on deepening the inter-academic cooperation in various areas and the unification of initial academic data;

- non-formal and adult education is aimed at increasing the knowledge, skills, and abilities are necessary for further professional growth and self-improvement.

The value of such international projects is to bring the education of a particular country to the level of world standards through its external financing, the exchange of best world experiences, and the 
involvement in global educational practice. Numerical sections on educational systems of Eastern European countries according to the criterion "International educational projects" supported by the World Bank in 2000-2019 are presented in Figure 1.

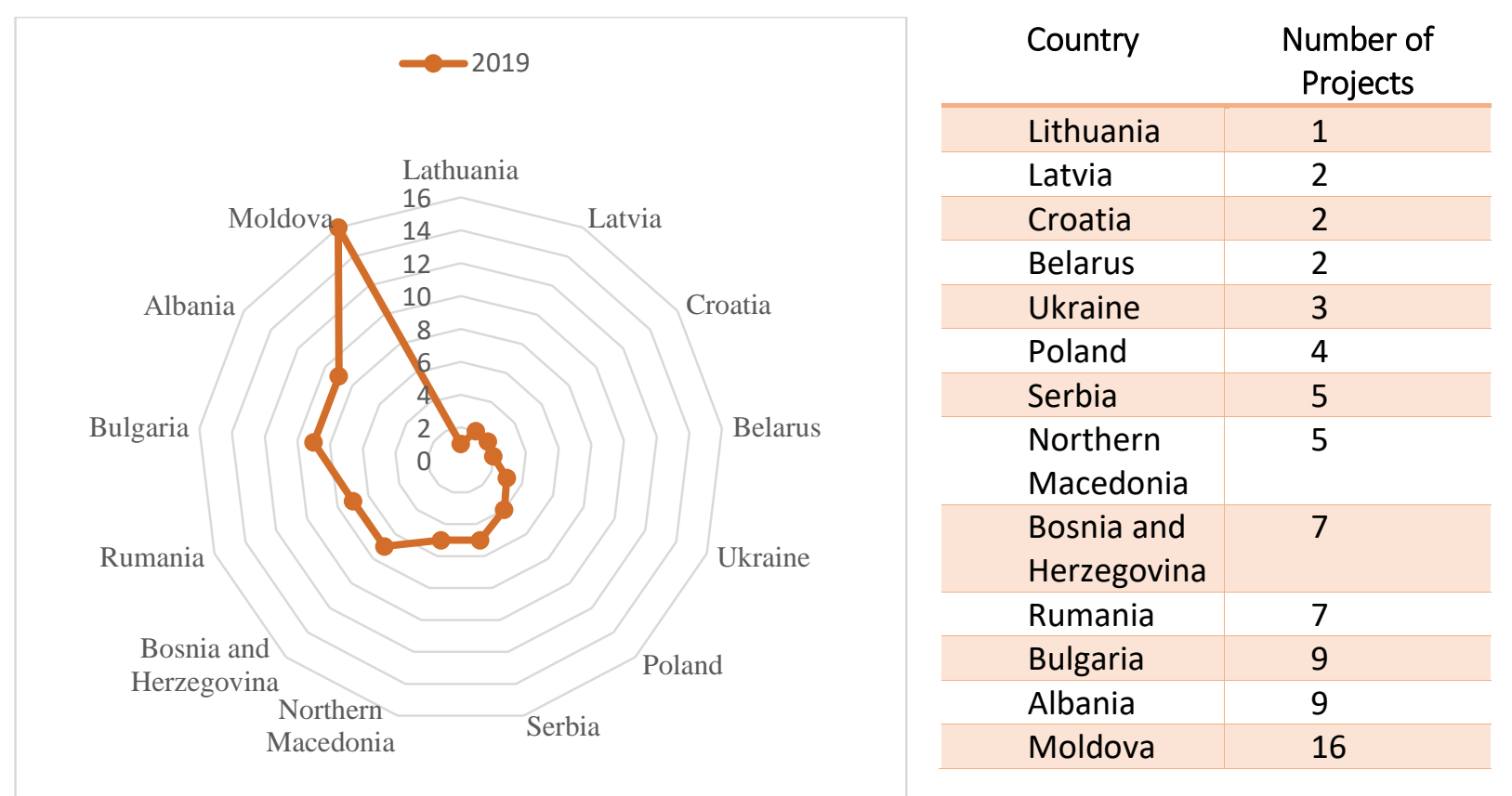

Figure 1 - The analysis of educational systems of Eastern European countries by the criterion of "International educational projects" supported by the World Bank (based on the thematic map "Projects", 2000-2019) (World Bank, 2020)

The figures in Figure 1 show that in Eastern European countries (including those involved in international educational projects led by the World Bank), the total number of these projects was about 72 units (World Bank, 2020). The highest rates, according to the World Bank, were achieved by three countries - Moldova, Albania, and Bulgaria (World Bank, 2020). In most countries from the proposed list, the number of international educational projects did not exceed 5 (in particular, Lithuania, Latvia, Croatia, Belarus, Ukraine, Poland, Serbia, and Northern Macedonia) (World Bank, 2020).

It should be emphasized that in this aspect, the role of the World Bank is primarily regulatory, not managerial. The priority task of such projects is to unify the educational policy of different countries. Funding for educational initiatives is aimed at achieving the country's appropriate performance in social and cultural growth.

The second thematic map is called "Knowledge" and is based on the involvement of a systems approach to the analysis of the studied groups, the so-called "S.A.B.E.R - Systems Approach for Better Education Results" (World Bank, 2020). Quantitative indicators of this thematic map reflect the actual data collected in the course of monitoring studies of educational systems. Unlike the previous thematic map, this one is based on comparing the total indicators for 5 sub-sectors of education - preschool, primary, secondary, higher, and vocational. The system approach to the analysis of the sub-sectors of education of the studied countries was based on the total number of criteria. In particular, their list includes the level of the intellectual development of the student; information support of the educational process; autonomy of the institution; financial support; valeological competence of participants of the educational process (Koval, Polyezhayev, Bezkhlibna, 2018); assessment of the quality of teaching and learning by the subjects of cognition (World Bank, 2020). 
Numerical sections of the educational systems of Eastern Europe according to the criterion "S.A.B.E.R" are presented in Figure 2.

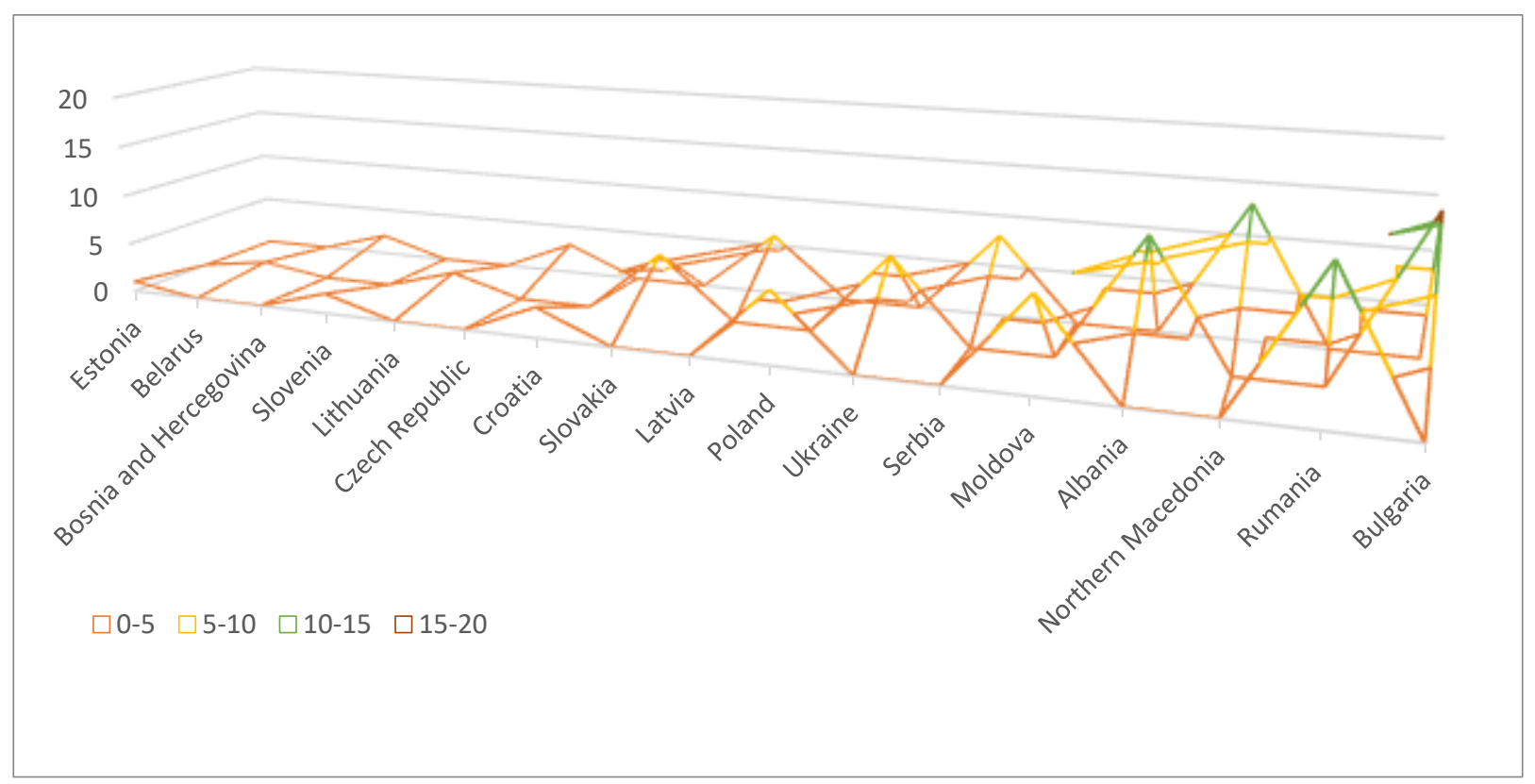

\begin{tabular}{|c|c|c|c|c|c|}
\hline Estonia & Belarus & $\begin{array}{l}\text { Bosnia and } \\
\text { Hercegovina }\end{array}$ & Slovenia & Lithuania & $\begin{array}{c}\text { Czech } \\
\text { Republic }\end{array}$ \\
\hline 1 & 1 & 2 & 2 & 2 & 3 \\
\hline Croatia & Slovakia & Latvia & Poland & Ukraine & Serbia \\
\hline 3 & 6 & 6 & 7 & 8 & 8 \\
\hline Moldova & Albania & $\begin{array}{l}\text { Nor } \\
\text { Mac }\end{array}$ & & Rumania & Bulgaria \\
\hline 9 & 12 & & & 14 & 16 \\
\hline
\end{tabular}

Figure 2 - Analysis of educational systems of Eastern European countries according to the criterion "S.A.B.E.R" supported by the World Bank (based on the thematic map "Knowledge", 20002019) (World Bank, 2020)

Visual materials showed that according to the "SABER" criterion, the first six leading positions were occupied by educational systems of such Eastern European countries as Bulgaria (16), Romania (14), Northern Macedonia (13), Albania (12), Moldova (9), Serbia, and Ukraine (both 8) (Fig. 2). At the same time, the lowest numerical indicators according to the studied criterion were showed by two countries - Estonia and Belarus (Fig. 2).

Comparing the analytical data on the educational systems of Eastern European countries on both criteria we noticed that in the latter case, some countries managed to achieve almost twice the quantitative indicators on the criterion "SABER", compared to the previous ones (in particular, Ukraine from 3 to 8; 4 to 7; Bulgaria from 9 to 16; Romania from 7 to 14; Lithuania from 1 to 2) (Fig. 1 and Fig. 2). In three countries of Eastern Europe, the opposite situation was observed, when the second criterion was inferior to the first, also almost twice (in particular, Belarus from 1 to 2; Bosnia and Herzegovina from 7 to 2; Moldova from 16 to 9) (Fig. 1 and Fig. 2). ). It is worth noting that the first criterion "International educational projects" is directly proportional to the external funding, while the second reproduces the internal approaches of the state to improve its educational system. 
Studying the level of development of educational systems around the world in detail, the issue of comparing the number of educational projects with their target orientation is becoming increasingly important. The rationality of comparing the latter by specific regions of the world and certain units of time (in particular, the calendar year) is rooted in the common problems of neighboring territories, which can be overcome only through the localization of interstate efforts.

On the World Bank website, we find the information on the target orientation and several educational projects in terms of the above-mentioned 6 regions of the world (World Bank, 2020). From the proposed list, Eastern Europe belongs to the region of Europe and Central Asia, and therefore the analysis will be based on the scientific principle of regionalism.

Analytical data on educational projects in the above-mentioned region supported by the World Bank in 2009-2019 are reflected in Table 1.

Table 1- Deepening the level of development of educational systems in Eastern Europe through external funding of educational projects in the region (2009-2019) (World Bank, 2020)

\begin{tabular}{|c|c|c|c|}
\hline Year & $\begin{array}{l}\text { Number of } \\
\text { projects }\end{array}$ & $\begin{array}{l}\text { Amount of funding } \\
\text { (million \$) }\end{array}$ & Target orientation of annual educational projects \\
\hline 2009 & 366 & 11 & $\begin{array}{l}\text { deepening the development of the industry through the } \\
\text { record funding for education }\end{array}$ \\
\hline 2010 & 621 & 8 & $\begin{array}{l}\text { maintaining gender equality in education and other } \\
\text { areas }\end{array}$ \\
\hline 2011 & 235 & 12 & investing in a ten-year school study program \\
\hline 2012 & 121 & 12 & $\begin{array}{l}\text { deepening development on the principle of affordable } \\
\text { education for all layers of the population }\end{array}$ \\
\hline 2013 & 87 & 6 & improving the general standard of living of the \\
\hline 2014 & 156 & 10 & population, including the financing of education \\
\hline 2015 & 380 & 7 & $\begin{array}{l}\text { realization of global goals of millennium development at } \\
\text { the level of educational systems of different countries of } \\
\text { the world }\end{array}$ \\
\hline 2016 & 104 & 6 & $\begin{array}{l}\text { support of educational projects aimed at meeting the } \\
\text { needs of girls (12-17 years) }\end{array}$ \\
\hline 2017 & 278 & 5 & a significant amount of funding for primary education \\
\hline 2018 & 44 & 4 & $\begin{array}{l}\text { exit from the educational crisis by improving the quality } \\
\text { of education }\end{array}$ \\
\hline 2019 & 574 & 5 & $\begin{array}{l}50 \% \text { reduction in poverty in education by the next thirty } \\
\text { years }\end{array}$ \\
\hline
\end{tabular}

The illustrative data of this table showed that the funding of educational projects in the region was unstable (Table 1). This process was a consequence of the impact on a particular phenomenon of external, as well as internal factors (in particular, fluctuations in GDP and exchange rates, unstable level of social and economic development) (Table 1). Another characteristic feature of these educational projects was that their number for one calendar year did not correspond to the total amount of their funding (million \$) (Table 1). The annual target orientation of such educational projects is also noticeable, which focused the society's attention on the need to establish appropriate values in education (in particular, maintaining gender equality, optimizing educational training, accessibility of all participants to the educational process, improving the quality of education, and reducing poverty). Table $1)$. 
To reflect the quantitative ratio of indicators for international educational projects in the region to the amount of their funding, the appropriate visual materials have been developed (see Fig. 3).

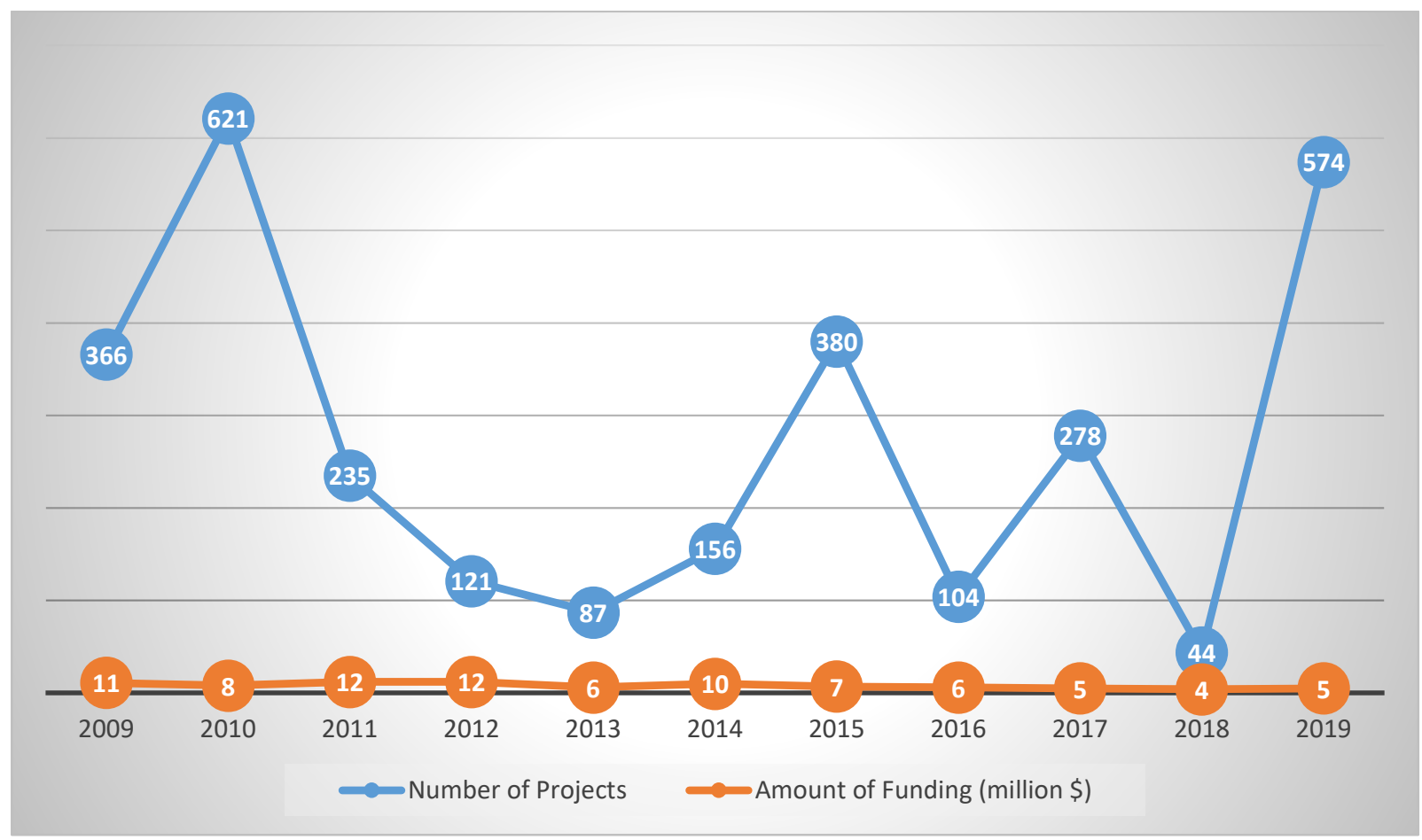

Number of Projects / Amount of Funding

Figure $\mathbf{2}$ - The ratio of the number of international educational projects in the studied region to the amount of external funding (million \$) over the last decade

The involvement of the method of comparative analysis in the reflection of specific quantitative parameters indicated in the figure made it possible to make brief generalizations. First, there have been abrupt fluctuations in the number of international educational projects over the last decade. We can assume that this consequent regularity was the result of the emergence of new innovative ideas in the field of education, which found adequate social support at the level of funding (Bukanov et al., 2019). On the straight line of axis $\mathrm{X}$, which is marked by the corresponding number of projects the highest indicators were recorded in 2012 and $2014-12$ and 10 (Fig. 3). However, despite such high numbers of projects, their total funding was not large. In particular, the latter fact indicates the low cost of one project in these calendar years.

Second, after a brief financial "decline", there was a leap in project funding the following year. Thus, the highest indicators of the number of international educational projects in the region were recorded in 2010 and 2019, the latter replacing the previous annual decline (in particular, from 366 to 621 and 44 to 574 , respectively) (Fig. 3).

Thus, the study of educational systems in Eastern Europe is a very multifaceted problem that requires the comparison of empirical data from the most reliable sources of information. Reconstruction of empirical data acquired from the international comparative research opens the way to the organization of intra-industry cooperation between different countries and contributes to the unification of current industry standards. 


\section{CONCLUSIONS}

Based on the above-considered information, we can conclude that the study of educational systems around the world is a single option associated with the involvement of international comparative studies. Such a regional approach to the organization of research today is one of the most promising at the scientific level. The advantage of such multidisciplinary research over mono-object research is that the former combined subject-object, methodological and functional-target features by involving empirical data. Such research is especially valuable for the analysis of educational systems around the world, which in the global dimension activates the increase of knowledge about existing international achievements and produces a deeper development of the education sector as a whole.

The analysis of educational systems of Eastern European countries was based on three basic criteria - international educational projects, the highest educational results ("S.A.B.E.R"), and the amount of external funding for the industry. This research approach made it possible to formulate several reasoned generalizations. The analysis of the subject of the study by the first criterion showed that in the studied countries of the region, there was an uneven distribution of international educational projects for a certain period. This could be caused by several factors, including different levels of social, economic, and cultural development, different levels of international cooperation development, membership of states in various international associations.

The involvement in the analysis of the second criterion allowed comparing educational systems of the countries of Eastern Europe on the following levels: intellectual development of the student; information support of the educational process; autonomy of the institution; valeological competence of participants in the educational process; assessment of the quality of teaching and learning by the subjects of cognition. The comparison of these indicators revealed three undisputed leaders (Bulgaria, Romania, and Northern Macedonia) and outsiders (Estonia, Belarus, and Bosnia and Herzegovina). Among the seventeen countries surveyed, Ukraine is in the middle of this ranking list.

The reflection of analytical data on the studied educational systems according to the third criterion showed that the number of educational projects and the amount of funding in the region are disproportionate indicators. Thus, such discrepancy of both indicators is rooted in the uneven impact on the phenomenon of external and internal factors (in particular, fluctuations in GDP and exchange rates, the level of social and economic development, etc.).

A comparative analysis of the level of development of educational systems in different countries of the world located within one geographical region, as well as on different continents can be a promising area of further research.

\section{References}

Bergbauer, A. B. (2019). How did EU membership of Eastern Europe affect student achievement? Education Economics, 27 (6), 624-644.

Bodnar, S., Mirkovich, I., Koval, V. (2019). Human capital development in Ukrainian education system by means of language integrated teaching. Dilemas contemporaneos-educacion politica y valores, 7 (SI), 14.

Bukanov H., Kolesnyk A., Tashkinova O., Kotlubai V., Koval V. (2019). Social marketing in public administration of social service institutions. Revista Genero \& Direito, 8 (6), 457-468. 
Dudka, T., Gurzhii, A., Kartashova, L., Sorochan, T. \& Spitsyna, A. (2020). Social and professional designing of tourist destination management in the professional training of future tourismologists. Revista Turismo Estudos \& Práticas, 2, 1-10.

Gawlicz, K. \& Starnawski, M. (2018). Educational policies in Central and Eastern Europe: legacies of state socialism, modernization aspirations and challenges of semi-peripheral contexts. Sage Journals, 14, 112-119.

Griffith, S. (2019). Teaching English in Central and Eastern Europe. A Guide to Job Prospects for Teaching English in Central and Eastern Europe, 4, 31-43.

Guglielmi, G. (2019). Eastern European universities score highly in university gender ranking. Nature research, 3, 11-24.

Hansen, J. U. \& Young K. (2019). Why It Is Time to Re-Imagine Our Education System. Real Clear Education. Retrieved from https://www.realcleareducation.com.

Kostetska, K., Khumarova, N., Umanska, Y., Shmygol, N., \& Koval, V. (2020). Institutional qualities of inclusive environmental management in sustainable economic development. Management Systems in Production Engineering, 28 (2), 15-22. https://doi.org/10.2478/mspe-2020-0003

Koval, V., Polyezhayev, Y., \& Bezkhlibna, A. (2018). Communicative competences in enhancing of regional competitiveness in the labour market. Baltic Journal of Economic Studies, 4(5), 105-113. doi:10.30525/22560742/2018-4-5-105-113

Kvitka, S., Starushenko, G., Koval, V., Deforzh, H., \& Prokopenko, O. (2019). Marketing of Ukrainian higher educational institutions representation based on modeling of Webometrics Ranking. Marketing and Management of Innovations, 3, 60-72. http://doi.org/10.21272/mmi.2019.3-05

Martinez, E. (2020). Pandemic shakes up world's education systems. Right to Education Initiative, 4, 1-12.

Mineo, L. (2020). Time to fix American education with race-for-space resolve. The Harvard Gazette. Retrieved from https://news.harvard.edu/gazette/story/2020/04/the-pandemics-impact-on-education

Mysíková, M., \& Večerník, J. (2019). Returns to Tertiary Education in Western and Eastern Europe. Prague Economic Papers, 1, 30-48.

Nazarova, K., Hordopolov, V., Kopotiienko, T., Miniailo, V., Koval, V., \& Diachenko, Y. (2019). Audit in the state economic security system. Management Theory and Studies for Rural Business and Infrastructure Development, 41(3), 419-430.

Osmond-Johnson, P., \& Campbell, C. (2018). Transforming an education system through professional learning: developing educational change at scale in Ontario. Educ Res Policy Prac 17, 241-256.

Panić, A., \& Lozanov-Crvenković Z. (2019). Analysis of Higher Education Indicators Coherency in Central and Eastern Europe. Business Systems Research Journal, 10 (2), 6-14.

Ralhan, B. D. (2020). Education 2020: Changing The Education System In India. Business world. Retrieved from http://www.businessworld.in/article/Education-2020-Changing-The-Education-System-In-India/14-072018-154491.

Rehmat, U. (2020). Education System in Pakistan. Education. Retrieved from https://rehmatblogger.com/education-system-pakistan. 
Rodberg, S. (2019). Data Was Supposed to Fix the U.S. Education System. Here's Why It Hasn't. Harvard Business Review. Retrieved from https://hbr.org/2019/01/data-was-supposed-to-fix-the-u-s-educationsystem-heres-why-it-hasnt.

Shmygol N., Galtsova O., Solovyov O., Koval V., Arsawan I. (2020). Analysis of country's competitiveness factors based on inter-state rating comparisons. E3S Web Conferences, 153, 03001. https://doi.org//10.1051/e3sconf/202015303001

Sonnemann, J. (2019). The top ranking education systems in the world aren't there by accident. Here's how Australia can climb up. News. Retrieved from https://www.abc. net.au /news/2019-12-04/top-rankingeducation-systems-in-world-arent-there-by accident.

Stepaniuk, I. (2019). Inclusive education in Eastern European countries: a current state and future directions. International Journal of Inclusive Education, 23 (3), 328-352.

Szerletics, A., \& Rodak, L. (2017). Introduction. Legal Education in Europe. Challenges and Prospects. Oñati Socio-legal Series, 7 (8), 1581-1588.

Ustun, U. \& Eryilmaz, A. (2018). Analysis of Finnish Education System to question the reasons behind Finnish success in PISA. Studies in Educational Research and Development, 2 (2), 93-114.

Waslander S., Hooge, E., Theisens, H., \& Cissy P. (2018). Steering in complex education systems. Why similar aims can have dramatically different results. Journal of Education Policy, 35 (2), 12-22.

World Bank (2020). Smart erucation. Retrieved from https://smartereducation.worldbank.org/projects.

Yankovyi O., Koval V., Trokhymets O., Karpenko M., Matskevich Y. (2020). Economic assessment of investment on the basis of production functions. Turismo: Estudos \&Práticas, 2.

\section{$\underline{\text { ABOUT THE AUTHORS }}$}

\section{Tetiana Dudka}

Department of Management and Innovative Technologies, Social and Cultural Activities, National Pedagogical Dragomanov University, Kyiv, Ukraine.

Email: kiev.professor@gmail.com

Orcid: https://orcid.org/0000-0003-4216-1083

\section{Mykola Chumak}

Department of Theories and Methods of Teaching Physics and Astronomy, National Pedagogical Dragomanov University, Kyiv, Ukraine.

Email: chumak.m.e@gmail.com

Orcid: https://orcid.org/0000-0002-9956-9429

\section{Nina Lytvynenko}

Department of Ukrainian Studies, Bogomolets National Medical University, Kyiv, Ukraine.

Email: nplytvynenko1@gmail.com

Orcid: https://orcid.org/0000-0002-6572-2392 


\section{Valentuna Benera}

Taras Shevchenko Regional Humanitarian-Pedagogical Academy of Kremenets, Kremenets, Ukraine. Email: val benera@ukr.net

Orcid: https://orcid.org/0000-0003-2865-3217

\section{Tamara Serhiienko}

Department of Ukrainian Studies, Bogomolets National Medical University, Kyiv, Ukraine.

Email: tamarasergiyenko@gmail.com

Orcid: https://orcid.org/0000-0003-2414-5418

Received in: 06-03-2020. Approved on: 07-07-2020.

Published on: 07-17-2020. 